\title{
Autoantibodies and Their Role in Scleroderma Clinical Care
}

\author{
Robyn T. Domsic, MD, MPH \\ Thomas A. Medsger Jr, MD
}

\author{
Address \\ *University of Pittsburgh, S724 Biomedical Science Tower, 200 Lothrop St., \\ Pittsburgh, PA, 15213, USA \\ Email: rtd4@pitt.edu
}

Published online: 14 June 2016

(C) Springer International Publishing AG 2016

This article is part of the Topical Collection on Scleroderma

Keywords Systemic sclerosis - Autoantibodies - Anti-nuclear antibodies

\section{Opinion statement}

The importance of autoantibodies in systemic sclerosis (SSc) diagnosis and prognosis has been increasingly recognized. This review discusses the current knowledge of autoantibodies in systemic sclerosis (SSc) with respect to clinical care. We focus primarily on the SSc-associated serum autoantibodies and their recognized SSc clinical phenotypes or characteristics. Geographic regional differences in autoantibody prevalence are discussed. Potential pitfalls in commercially available autoantibody testing are considered. Finally, contemporary literature in regards to antibodies to functional molecules is reviewed.

\section{Introduction}

For many decades, experienced clinicians have recognized that systemic sclerosis (SSc or scleroderma) is a highly heterogeneous disease in its clinical presentation, organ system involvement, natural history, and prognosis. In 1988, an international consensus statement recognized that two major disease subsets are present based on the extent of skin thickening [1]. This publication described the major features of diffuse cutaneous and limited cutaneous (previously termed CREST syndrome) SSc and noted the association of serum antitopoisomerase I antibody (Scl-70) with diffuse SSc and anti-centromere antibody with limited SSc.

Since that time, there have been additional refinements. First, more precise, mutually exclusive definitions have been proposed for diffuse and limited SSc. Diffuse SSc patients have skin thickness proximal to the elbows and knees (upper arms, thighs, anterior chest, or abdomen) at some time during the disease, whereas in limited SSc patients, skin thickening remains restricted to the distal extremities (distal to the elbows and knees). Second, it is clear that SSc patients with no skin thickening (SSc sine scleroderma or ssSSc) are part of the limited SSc spectrum [2] and approximately $4 \%$ of the total SSc population [3]. Finally, both diffuse and limited SSC can coexist with another connective tissue disease (CTD) as an overlap syndrome, most frequently one of the inflammatory myopathies, but also systemic lupus erythematosus (SLE) or inflammatory arthritis.

In addition, new SSc-related serum autoantibodies have been described, along with their clinical associations. Today, over $95 \%$ of SSc patients have a positive antinuclear antibody (ANA) test, and over $85 \%$ have 
one or more autoantibodies either restricted to (specific for) or most commonly detected in (strongly associated) with SSc. All of these antibodies are directed against nuclear antigens and are thus antinuclear antibodies (ANAs). Detection of these autoantibodies aids in diagnosis and prognosis [4]. The importance of SScassociated autoantibodies has been recently recognized in the new combined American College of Rheumatology (ACR)/European League Against Rheumatism

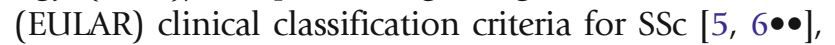
which incorporate the presence of three autoantibodies (anti-Scl-70, anti-RNA polymerase III (RNAP), and anticentromere) as supporting the classification of SSc.

The combination of clinical classification by extent of skin thickening, augmented by serologic status by autoantibody type, has allowed a clinical-serologic classification of SSc (Fig. 1) which has proved to be very helpful for managing physicians, clinical and laboratory investigators, and patients. In this chapter, we will use this combined clinical-serologic classification system to focus on the role of the currently recognized ten SSc-associated serum autoantibodies in patient care and management. We will highlight recent publications.

In addition, a new group of autoantibodies reactive with functional proteins, such as cell surface receptors and extracellular matrix proteins, has been identified in SSc patients. They may contribute to disease pathogenesis by activating pathways involved in damaging vascular endothelial cells or promoting fibrosis. These will be reviewed under the section header, "Antibodies to Functional Molecules."

\section{SSc-associated ANAs}

As of this writing, ten ANA specificities associated with SSc have been reported and characterized, the most newly recognized autoantibody published in 2014. The original methods of antibody detection have included ANA by indirect immunofluorescence (IIF), double immunodiffusion (DID), and immunoprecipitation (IP). Today, ELISA and bead-based testing are more commonly used but have specific and significant limitations in SSc patients (see subheading "Important Clinical Limitations of Commercial Antibody Testing in SSc Patients" below).

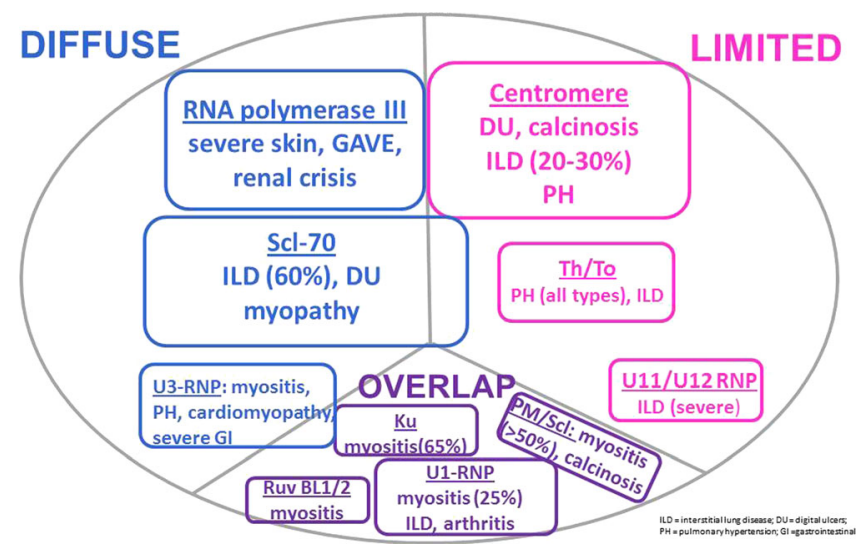

Fig. 1. Proportional representation of autoantibody frequencies, and their associations with cutaneous subtypes and internal organ manifestations. 
These antibodies are rarely found in patients with other connective tissue diseases (CTDs) unless SSc features are also present, and thus, they are important diagnostic markers. The antibodies are nearly always present when first tested, and their presence likely precedes clinical findings by months or years, as has been confirmed in RA and SLE [7, 8]. SSc antibodies typically remain detectable throughout the course of disease, independent of treatment. SSc patients seldom (2-3\%) have more than one of these SSc-associated antibodies, suggesting that they occur in a mutually exclusive fashion. This statement does not include coexistence with SSA or Ro antibodies, which can occur in some SSc patients, and supports the possibility of coexistent Sjogren syndrome. In the Pittsburgh experience, anti-U1RNP is the autoantibody seen most frequently in combination with other SSc-associated antibodies.

Of interest, there is geographical variation in autoantibody frequencies as depicted in Table 1. These differences in regional autoantibody prevalence likely determine the phenotypic differences and reported predictors of prognosis and mortality reported in regional cohort studies.

Table 1. Worldwide frequency of SSc-related autoantibodies

\begin{tabular}{|c|c|c|c|c|}
\hline & Europe & North America & Asia & Australia \\
\hline Anti-topoisomerase & $\begin{array}{l}37 \% \text { EUSTAR } \\
24 \% \text { Belgium } \\
30 \% \text { Germany } \\
20 \% \text { UK }\end{array}$ & $\begin{array}{l}18 \% \text { Pittsburgh } \\
16 \% \text { Canada } \\
28 \% \text { Mexico }\end{array}$ & $10 \%$ Malaysia & $18 \%$ \\
\hline Anti-RNA polymerase III & $\begin{array}{l}2 \% \text { EUSTAR } \\
6-9 \% \text { France } \\
6 \% \text { Belgium } \\
4-7 \% \text { Germany } \\
17 \% \text { UK }\end{array}$ & $\begin{array}{l}22 \% \text { Pittsburgh } \\
14 \% \text { Canada } \\
1 \% \text { Mexico }\end{array}$ & 6-10 \% Japan & $13-15 \%$ \\
\hline Anti-U3RNP & $3 \%$ UK & $\begin{array}{l}3 \% \text { Pittsburgh } \\
1 \% \text { Canada }\end{array}$ & $10 \%$ Malaysia & \\
\hline Anti-centromere & $\begin{array}{l}32 \% \text { EUSTAR } \\
41 \% \text { Belgium } \\
36 \% \text { Germany } \\
32 \% \text { UK }\end{array}$ & $\begin{array}{l}19 \% \text { Pittsburgh } \\
30 \% \text { Mexico } \\
39 \% \text { Canada }\end{array}$ & $10 \%$ Malaysia & $41 \%$ \\
\hline Anti-Th/To & & $8 \%$ Pittsburgh & & \\
\hline Anti-U1RNP & $\begin{array}{l}5 \% \text { Germany } \\
5 \% \text { Belgium }\end{array}$ & $5 \%$ Pittsburgh & & \\
\hline Anti-PM/Scl & $\begin{array}{l}5 \% \text { Germany } \\
5 \% \text { UK }\end{array}$ & $\begin{array}{l}4 \% \text { Pittsburgh } \\
3 \% \text { Canada } \\
9 \% \text { Mexico }\end{array}$ & & \\
\hline Anti-Ku & $1 \%$ Germany & $\begin{array}{l}1 \% \text { Pittsburgh } \\
1 \% \text { Canada } \\
10 \% \text { Mexico }\end{array}$ & & \\
\hline Anti-U11/U12 RNP & - & $2 \%$ Pittsburgh & $2 \%$ Japan & - \\
\hline Anti-RuvBL1/2 & - & $1 \%$ Pittsburgh & $2 \%$ Japan & - \\
\hline
\end{tabular}




\section{Anti-centromere antibody}

Anti-centromere antibody (ACA) is directed against centromere proteins, and the gold-standard method of detection is by ANA using indirect immunofluorescence, and is widely available. Centromere proteins are necessary in the assembly of the kinetochore during cell division and are essential to mitosis. Recent work has confirmed that there are two centromere epitopes recognized, centromere-A and centromere-B. SSc patient antibodies can react to both centromere antigens. Centromere-A has greater specificity in SSc patients [9], but centromere- $\mathrm{B}$ antigen is the antigen included in most commercially available ELISA kits and multiplex assays. Anti-centromere-A antibodies are not part of naturally occurring human immunoglobulins [10]. Two novel motifs within the immunodominant centromere-A epitope have been identified, one of which is Ap17-30. Interestingly, this motif appears to be within the primary sequence of FOXE-3, which is a transcription factor known to be involved in the development of lens fiber cells. New work has demonstrated that FOXE-3 is expressed in monocytes, and that SSc patients with distinct seropositivity responded differently to cytokine stimulation [11].

ACA occurs in $20-25 \%$ of most SSc populations and is strongly associated with limited SSc (Fig. 1) and scleroderma sine scleroderma. The prototypical ACA-positive SSc patient has long-standing (years) Raynaud phenomenon followed by swollen fingers (sclerodactyly) and then by thickening of the skin of the fingers which evolves over a number of years or even decades. For patients with Raynaud symptoms and no other clinical clues to an underlying CTD, the presence of ACA and/or nailfold capillary abnormalities is strongly predictive of the subsequent development of SSc [12]. Digital ischemia with digital tip ulcerations is disproportionately frequent in ACA-positive patients $[13 \bullet \bullet$. Esophageal involvement is common $(80 \%)$, but severe interstitial lung disease, cardiomyopathy, and scleroderma renal crisis (SRC) are rare $[14 \bullet \bullet, 15]$. The most serious long-term complications of ACApositive SSc are the late occurrence of pulmonary arterial hypertension

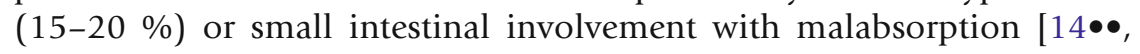
$15]$.

\section{Anti-topoisomerase I (Anti-Scl-70) antibody}

This antibody is found in 20-30\% of SSc patients in many ethnic groups, but in Europe, the proportion is higher $(40-60 \%)$ [16••]. Three-fourths of patients with this antibody have dcSSc (Fig. 1). There is a high (60\%) risk of interstitial lung disease (ILD) regardless of the extent of skin thickening (diffuse or limited) [17].

Anti-Scl-70 is associated with myocardial disease and scleroderma renal crisis (SRC) in patients with rapidly progressive diffuse skin involvement [17]. Peripheral vascular complications such as digital ischemia with ulcerations are particularly common. In the multicenter digital ulcer outcome (DUO) registry,

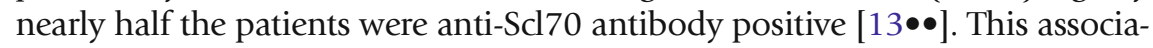
tion was confirmed in a recent EUSTAR multivariate analysis [18] where anti- 
Scl-70 was an independent predictor of developing subsequent digital ulcers. Anti-Scl-70 is a marker for poor prognosis, primarily because of its association with ILD and its sequelae including secondary pulmonary hypertension.

The most reliable method for detecting anti-Scl 70, double immunodiffusion, has now been replaced in most commercial laboratories by ELISA or beadbased assays. Unfortunately, these methods result in a number of "low positives" which are, in fact, false positive tests in persons who do not have clinical evidence of SSc and often have a negative ANA by IIF. Clinicians should be cognizant of this when evaluating patients with a positive Scl-70 antibody test.

\section{Anti-RNA polymerase III antibody}

Anti-RNA polymerase III (RNAP III) is highly specific to SSc. The gold-standard method of detection is by immunoprecipitation, but reliable ELISA-based tests are commercially available. There is a higher frequency in North America Caucasian and UK patients (20-25\%) in comparison with mainland European or Japanese patients $(5 \%)[16 \bullet \bullet, 19]$. Almost all patients with RNA P III have rapidly progressive diffuse skin thickening (Fig. 1). The peak skin thickness score is higher in RNAP III than in Scl 70 patients (Pittsburgh unpublished data),[20], and recent EUSTAR work has demonstrated that a higher rate of RNAP III-positive patients develop diffuse SSc within 3 years of the onset of Raynaud phenomenon than Scl-70-positive patients [18]. In many patients, skin thickness regresses during follow-up, even without treatment.

SSc patients with this antibody have the greatest risk for developing SRC (25\%) [21], typically during the early period when skin thickness progression is accelerated, and if tendon friction rubs are appreciated. Once SRC has occurred, survival is better than in Scl-70 positive SRC patients, perhaps because concomitant severe ILD and cardiomyopathy are infrequent in RNAP III patients.

In the last few years, two new associations with RNAP have come to light. The first is the occurrence of gastric antral vascular ectasia (GAVE or "watermelon stomach"), confirmed in two cohort studies [22, 23]. The second is a close temporal relationship between the onset of SSc in RNAP III-positive patients and the diagnosis of cancer, suggesting that the SSc may be a

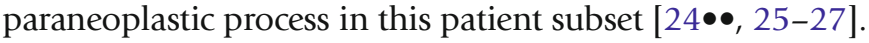

\section{Anti-U3RNP antibody [28]}

This antibody reacts with 34-KD fibrillarin complexed with U3RNA and produces bright nucleolar staining on ANA IIF testing. A reliable ELISA test is commercially available for detection of this antibody, and a recent publication suggested that a line immunoblot assay may be an attractive alternative [29]. Some commercial laboratories do have available immunoprecipitation testing, which is the gold standard.

Anti-U3RNP is found in $4-10 \%$ of SSc patients and is more frequent in African Americans $[28,30]$. It has been linked to a specific HLADRB $1{ }^{*} 08-04$ allele [31] in African Americans. More than half of patients have diffuse SSc. A non-inflammatory skeletal myopathy is a distinctive feature, and early severe internal organ involvement including cardiomyopathy, PAH, and small bowel involvement with malabsorption and 


\section{Anti-Th/To antibody}

episodes of pseudoobstruction may occur [19]. Prognosis in this subset of SSc patients is poor [30], similar to those with anti-Scl-70 antibody.

These antibodies are directed against subunits of mitochondrial RNA processing and ribonuclease P RNP complexes. Most patients with anti-Th/To antibody have nucleolar staining on ANA by IIF. One US-based company offers a commercially available immunoprecipitation assay for this test. Th/To antibody occurs in less than $5 \%$ of SSc patients, almost all of whom have limited SSc (Fig. 1). Patients with this antibody can develop either ILD (45 \%) or PAH ( $25 \%)$, which are most often independent of one another [15]. These pulmonary complications result in a reduced survival compared to lcSSc patients with other SSc-associated antibodies. Regular screening for PAH in this patient population is prudent.

\section{Anti-U11/U12RNP antibody}

This is a rare antibody found in 1-3\% of SSc patients, equally divided between limited and diffuse subtypes (Fig. 1). A distinctive clinical feature is a very high frequency of ILD $(80 \%)$ which is often severe and rapidly progressive. As of this writing, there has only been one publication examining the internal organ associations with this autoantibody [32]. To the author's knowledge, testing for this antibody is not commercially available at this time.

\section{Anti-PM/Scl antibody}

$\mathrm{PM} / \mathrm{Scl}$ antibodies target the human exosome complex, of which there are up to 16 proteins. The major B cell targets of the PM/Scl complex have been identified as PM100 (also called PM1-alpha) and PM75. SSc patients can have antibodies to one or both of these antigens. PM/Scl is one of three SScassociated autoantibodies that have predominantly nucleolar staining on ANA by IIF, often with a moderately high ANA titer level. The gold-standard detection method for PM/Scl has been immunodiffusion and can be obtained commercially. The PM100 is available commercially using semiquantitative immunblot testing.

Two to $4 \%$ of SSc patients have anti-PM/Scl [33-35]. Patients with anti-PM/Scl antibody most often have an overlap with features of limited SSc and polymyositis (Fig. 1), but some have myositis only [36]. The myositis is usually mild and corticosteroid-responsive. Although there is a relatively high percentage of patients with lung involvement (40-50\%), serious internal organ involvement is rare, and patients have an excellent prognosis [33,34]. Calcinosis has been

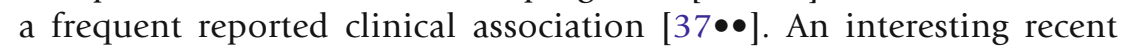
article combined Canadian, Australian, and US samples to examine the clinical associations with antibodies to each or both of the PM/Scl 
Anti-Ku antibody

complexes [34]. The presence of autoantibodies to both complexes was associated with an increased rate of inflammatory myositis.

The Ku antigen is a heterodimer of $70 \mathrm{kDa}(\mathrm{p} 70)$ and $80 \mathrm{kDa}(\mathrm{p} 80)$ subunits. $\mathrm{Ku}$ is a multifunctional protein involved in DNA repair, immunoglobulin gene recombination, and transcription regulation [38]. Commercial testing for this antibody is available using immunoprecipitation through specific myositis testing panels. Anti-Ku patients represent less than $2 \%$ of SSc populations, and anti-Ku has most commonly been detected in limited SSc patients with overlap

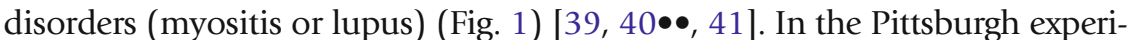
ence, $60 \%$ developed diffuse SSc skin changes. A more recent publication has linked it to a relatively higher rate of ILD [39] and several with arthritis [39, 41]. Although there are several case series of anti-Ku-positive SSc patients, overall numbers reported remain small, and thus, an estimate regarding prognosis cannot be made. The associated myositis is typically corticosteroid-responsive [42].

Anti-U1RNP antibody

This antibody was initially identified by Sharp et al. in the 1970s as being associated with features of SSc, PM and SLE and was thus considered to describe "mixed connective tissue disease" or MCTD [43]. Various combinations of these CTDs have been reported, and some patients have few or no scleroderma features. When we encounter anti-U1RNP-positive patients who have predominantly scleroderma features, we classify them as having SSc rather than using the term MCTD. High-titer speckled nuclear staining is most frequently found on ANA by IIF. Disease onset tends to be at a relatively young age, and limited SSc is far more common than diffuse SSc. The presence of arthritis and myositis is included in all proposed criteria for MCTD [44-47]. Five to $10 \%$ of SSc patients have anti-U1RNP, which is particularly common in African American and Asian patients [28]. Serious complications are relatively uncommon. In our experience, the PAH that occasionally develops in anti-U1RNP-positive SSc patients is responsive to corticosteroids and immunosuppressive agents, which is not typically the case in PAH associated with other SSc antibodies.

\section{Anti-RuvBL1/2 antibody}

This newly identified antibody is directed against a double hexamer containing the proteins pontin and reptin, located in the nucleoplasm (Fig. 1). Detection is by immunoprecipitation less than $1 \%$ of SSc patients have this antibody, which is more common in males with diffuse skin thickening and coexistent myositis. Only one publication, combining single cohorts from Japan and the US have reported [48••]. Information on internal organ and prognosis is limited at this time. To our knowledge, this antibody cannot be identified in a commercial setting at present. 


\section{Other SSc-associated ANAs}

\section{ANA-negative SSC}

Anti-nucleolar organizing region (NOR) antibodies [49], anti-B23 [50], antiSSA/R052/TRIMZ1 [51] antibodies to interferon-inducible genes designated HIN-200 [52], and antibodies to cytoplasmic mitochondrial proteins [53] have been reported in SSc patients. Anti-B23 was noted to be associated with PAH, but often coexisted with anti-U3RNP and anti-U1RNP; thus, its independent association with PAH is uncertain [51]. Anti-R052TRIM is strongly associated with SSc overlap syndromes and ILD [52].

Fewer than $5 \%$ of patients with documented SSc on clinical grounds are ANA negative. A large North American SSc registry reported $6 \%$ ANA-negative patients who were mostly males with less vasculopathy and an increase in lower gastrointestinal involvement [54].

\section{Important clinical limitations of commercial antibody testing in SSc patients}

In addition to the problem of false positive anti-Scl-70 antibody results, there are other issues with newer commercially available immunoassays that have been revealed recently. The majority of these assays require the availability of highly purified autoantigens, which contain the major epitopes recognized by virtually all sera positive for given SSc-related ANAs. However, since most autoantigens recognized by SSc ANAs are multiprotein complexes, determining the antigenic subunit most commonly recognized by autoantibodies is a major challenge.

Bead-based multiplex assay testing, which combines multibead arrays and flow cytometry, is capable of detecting multiple SSc-associated nuclear antibodies simultaneously. Unfortunately, in the commercially available multiplex ANA assays, many of the SSc-associated antibodies are not present. Although the common antibodies of centromere, Scl70 and U1RNP antigens are included, the other seven SSc-associated antigens are not included. Thus, when this type of assay was used for ANA screening, up to $50 \%$ of SSc patients were reported as a negative ANA in the US population [55] despite the fact that $>90 \%$ would have had a positive ANA test by immunofluorescence. Use of beadbased ANA testing for screening holds a potential danger for missing SSc patients, particularly at the primary care level.

More recently, a EUROLINE tests has become available which can detect multiple SSc-associated antibodies (PM/Scl, Ku, Scl-70, centromere-B, RNAP III, U3-RNP, Th/To as well as additional specificities). This immunoblot assay produces semi-quantitative results. Although not 
the primary goal of the publication, recent work from the Australian Scleroderma Cohort Study using the EUROLINE test demonstrated that the rate of multiple antibody positivity was far higher than in cohorts that use the gold-standard testing, including immunodiffusion, suggesting high rates of false positivity using the EUROLINE test. In their principal component analysis, they demonstrated that the dominant autoantibody (if Scl-70, RNAP, or ACA) accurately reflects disease associations with this testing. We recommend caution in interpreting other results with this assay.

In the SSc literature, authors have commonly grouped and analyzed together patients presenting with a nucleolar pattern on ANA testing by immunofluorescence. The nucleolar pattern generally corresponds to one of three SSc-associated antibodies: anti-PM/Scl, anti-U3RNP, or anti-Th/To. Since the clinical and laboratory associations, internal organ involvement, and natural history of disease differ considerably in these three antibody subsets (see above sections), it is important to identify each if possible, both for patient care and research. Until very recently, the latter two of these antibodies could not be performed commercially and thus, have not usually been identified in cohort studies and clinical trials. This is an area in which the SSc community should work together in the future to identify and support resource laboratories capable of performing these tests in a reliable and validated manner.

\section{Usefulness of SSc-related ANAs in SSc diagnosis}

These antibodies are useful in supporting the diagnosis of SSc primarily because of their high specificity for the disease. As a consequence, the presence of ACA, anti-Scl-70, and anti-RNAP III are included in the serologic domain of the 2013 classification criteria for SSc jointly proposed by the American College of Rheumatology (ACR) and the European League against Rheumatism (EULAR). Their high specificity and the availability of reliable assay kits worldwide accounts for their inclusion in the criteria set.

\section{Usefulness of SSc-related ANAs regarding disease activity}

It has generally been believed that serial measurement of serum ANA titers is not useful in assessing SSc disease activity. However, few such studies have been attempted, and in the past, quantitation of antibody levels was not possible. Changing levels of anti-Scl 70 by ELISA were found to be associated with progression of skin thickness [63], and patients who lost anti-Scl 70 antibody reactivity over time had a more favorable outcome [55, 64]. Anti-RNAP III antibody levels correlated positively with the modified Rodnan total skin thickness score and with 


\section{Antibodies to functional molecules}

the onset of scleroderma renal crisis (SRC). Now that semi-quantitative methods are available, additional studies are likely to be performed to clarify the usefulness of serial autoantibody testing in predicting future events in clinical practice and clinical trials.

\section{Antibodies to function}

These autoantibodies are potentially relevant to SSc pathogenesis by modulating disease-related pathways such as platelet-derived growth factor [56], transforming growth factor beta [57], angiotensin II type 1 receptor [58], or endothelin-1 type a receptor [59]. They have been reviewed in a recent textbook chapter [57]. Overall, the potential clinical utility of these autoantibodies remains uncertain. We will briefly discuss focused recent work examining antiendothelin 1 type A receptors (ETAR) and anti-angiotensin II type I receptor (AT1R) in SSc which is relevant to patient care.

Serum AT1R and ETAR antibodies were reported to be elevated in autoimmune diseases [59] and in pre-eclampsia [60]. These antibodies have been found in human microvascular endothelial cells, but also are expressed in fibroblasts, epithelial, and immune cells. These antibodies have been shown to be biologically active and potentially mediate pathogenic effects of SSc [61]. Riemekasten et al. showed in a cross-sectional cohort study that there was an association between these antibodies and SSc mortality, pulmonary hypertension, renal crisis, and digital ulcers [59]. In 2015, Avouac et al. examined a small $(n=90)$, prospective SSc cohort and showed anti-ETAR antibodies to be an independent predictor of the occurrence of new ischemic DU over 48 months, but not antiAT1R. A history of DU was also important in their models [62]. This work suggests a potential promising role of anti-ETAR and perhaps AT1R in future clinical management or risk stratification in study design of digital ulcers.

\section{Conclusions}

Systemic sclerosis-associated serum autoantibodies support the diagnosis of SSc, and because of their strong clinical associations they compliment the cutaneous-based subgrouping of SSc patients. A combined clinical-serologic classification system provides an essential framework for predicting patterns and frequency of organ system involvement in SSc patients. This is helpful for patient management and informing the design and conduct of future clinical and laboratory research and clinical trials.

\section{Compliance with Ethical Standards}

\section{Conflict of Interest}

RTD reports research support from Biogen-idec and personal fees and research support from Bayer Healthcare, outside the submitted work. TAM declares that he has no conflicts of interest. 


\section{Human and Animal Rights and Informed Consent}

With regard to the authors' research cited in this paper, all procedures performed in studies involving human participants were in accordance with the ethical standards of the institutional and/or national research committee and with the 1964 Helsinki declaration and its later amendments or comparable ethical standards. In addition, all applicable international, national, and/or institutional guidelines for the care and use of animals were followed.

\section{References and Recommended Reading}

Papers of particular interest, published recently, have been highlighted as:

- Of major importance

1. LeRoy EC et al. Scleroderma (systemic sclerosis): classification subsets and pathogenesis. J Rheumatol. 1988;15(2):202-5.

2. Poormoghim H, Lucas M, Fertign, Medsger Jr TA. Systemic sclerosis sine scleroderma: demographic, clinical and serologic features and survival in forty-eight patients. Arthritis Rheum 2000;43:444-51.

3. Diab S, Dostrovsky N, Hudson M, Tatibouet S, Fritzler MJ, Baron M, et al. Systemic sclerosis sine scleroderma: a multicenter study of 1417 subjects. J Rheumatol. 2014;41(11):790-85.

4. Nihtyanova SID. Autoantibodies as predictive tools in systemic sclerosis. Nat Rev Rheumatol. 2010;5:112-6.

5. van den Hoogen F et al. 2013 classification criteria for systemic sclerosis: an American College of Rheumatology/European League Against Rheumatism collaborative initiative. Arthritis Rheum. 2013;65(11):2737-47.

6.• van den Hoogen $F$ et al. 2013 classification criteria for systemic sclerosis: an American College of Rheumatology/European League Against Rheumatism collaborative initiative. Ann Rheum Dis. 2013;72(11):1747-55.

This article presents the new systemic sclerosis classification criteria, which now includes SSc-specific antibodies.

7. Arbuckle MR, McClain MT, Rubertone MV, Scofield RH, Dennis GJ, James JA, et al. Development of autoantibodies before the clinical onset of systemic lupus erythematosus. N Engl J Med. 2003;349(16):1526-33.

8. Shi J, van de Stadt LA, Levarht EW, Huizinga TW, Hamann D, van Schaardenburg D, et al. Anticarbamylated protein (anti-CarP) antibodies precede the onset of rheumatoid arthritis. Ann Rheum Dis. 2014;73(4):780-3.

9. Perosa F, Favoino E, Cuomo G, Digiglio L, Dammacco $\mathrm{F}$, Prete $\mathrm{M}$, et al. Clinical correlates of a subset of antiCENP-A antibodies cross-reacting with FOXE3p53-62 in systemic sclerosis. Arthritis Res Ther. 2013;15(4):R72.

10. Peroso F, Prete M, DiLernia G, Ostuni C, Favoino E, Valentini G. Anti-centromere protein A antibodies in systemic sclerosis: significance and origin. Autoimmun Rev. 2015;15(1):105-9.

11. Favoino E, Favia I, Valentini G, Perosa F. Expression of the transcription factor Forkhead Box E3 (Foxe3) in monocytes from patients with systemic sclerosis and correlation with their serological profile. Ann Rheum Dis. 2014;73:868.

12. Koenig M, Joyal F, Fritzler MJ, Roussin A, Abrahamowicz M, Boire G, et al. Autoantibodies and microvascular damage are independent predictive factors for the progression of Raynaud's phenomenon to systemic sclerosis: a twenty-year prospective study of 586 patients with validation of proposed criteria for early systemic sclerosis. Arthritis Rheum. 2008;58(12):3902-12.

13.• Denton CP, Krieg T, Guillevin L, Schwierin B, Rosenberg D, Silkey M, et al. DUO Registry investigators demographic clinical and antibody characteristics of patients with digital ulcers in systemic sclerosis: data from the DUO Registry. Ann Rheum Dis. 2012;71(5):718-21.

This article presents antibody associations with the development of digital ulcerations.

$14 . \bullet$ Hudson M, Mahler M, Pope J, You D, Tatibouet S, Steele R, et al. Clinical correlates of CENP-A and CENP$\mathrm{B}$ antibodies in a large cohort of patients with systemic sclerosis. J Rheumatol. 2012;39(4):787-94.

This article reports associations with centromere antibodies subtypes.

15. Mitri GM, Lucas M, Fertig N, Steen VD, Medsger JrTA. A comparison between anti-Th/To- and anticentromere antibody-positive systemic sclerosis patients with limited cutaneous involvement. Arthritis Rheum. 2003;48(1):203-9.

16.• Meier FM, Frommer KW, Dinser R, Walker UA, Czirjak $\mathrm{L}$, Denton CP, et al. Update on the profile of the EUSTAR cohort: an analysis of the EULAR Scleroderma Trials and Research group database. Ann Rheum Dis. 2012;71(8):1355-60.

This article includes information on SSc-associated antibody frequencies and clinical characteristics in a large, multicenter, European cohort. 
17. Perera A, Fertig N, Lucas M, Rodriguez-Reyna TS, Hu P, Steen VD, et al. Clinical subsets skin thickness progression rate and serum antibody levels in systemic sclerosis patients with anti-topoisomerase I antibody. Arthritis Rheum. 2007;56(8):2740-6.

18. Wirz EG, Jaeger VK, Allanore Y, Riemekasten G, Hachulla E, Distler O, Airò P, Carreira PE, Tikly M, Vettori S, Balbir Gurman A, Damjanov N, MüllerLadner U, Distler J, Li M, Häusermann P, Walker UA, EUSTAR coauthors. Incidence and predictors of cutaneous manifestations during the early course of systemic sclerosis: a 10-year longitudinal study from the EUSTAR database. Ann Rheum Dis 2013.

19. Hamaguchi Y, Hasegawa M, Fujimoto M, Matsushita T, Komura K, Kaji K, et al. The clinical relevance of serum antinuclear antibodies in Japanese patients with systemic sclerosis. Br J Dermatol. 2008;158(3):487-95.

20. Nikpour M, Hissaria P, Byron J, Sahhar J, Micallef M, Paspaliaris W, et al. Prevalence correlates and clinical usefulness of antibodies to RNA polymerase III in systemic sclerosis: a cross-sectional analysis of data from an Australian cohort. Arthritis Res Ther.

2011;13(6):R211.

21. Hamaguchi $Y$, Kodera $M$, Matsushita $T$, Hasegawa $M$, Inaba Y, Usuda T, et al. Clinical and immunologic predictors of scleroderma renal crisis in Japanese systemic sclerosis patients with anti-RNA polymerase III autoantibodies. Arthritis Rhematol. 2015;67(4):104552.

22. Ghrénassia E, Avouac J, Khanna D, Derk CT, Distler O, Suliman YA, et al. Prevalence correlates and outcomes of gastric antral vascular ectasia in systemic sclerosis: a EUSTAR case-control study. J Rheumatol. 2014;41(1):99-105.

23. Patterson KA, Roberts-Thomson PJ, Lester S, Tan JA, Hakendorf $\mathrm{P}$, Rischmueller $\mathrm{M}$, et al. Interpretation of an extended autoantibody profile in a wellcharacterized Australian systemic sclerosis (scleroderma) cohort using principal components analysis. Arthritis Rheumatol. 2015;67(12):3234-44.

24.• Shah AA, Rosen A, Hummers L, Wigley F, CasciolaRosen L. Close temporal relationship between onset of cancer and scleroderma in patients with RNA polymerase I/III antibodies. Arthritis Rheum. 2010;62(9):2787-95.

Original article describing the temporal association between RNA polymerase III and onset of SSc.

25. Airo P, Ceribelli A, Cavazzana I, Taraborelli M, Zingarelli S, Franceschini F. Malignancies in Italian patients with systemic sclerosis positive for anti-RNA polymerase III antibodies. J Rheumatol. 2011;38(7):1329-34.

26. Moinzadeh $P$, Fonseca $C$, Hellmich $M$, Shah AA, Chighizola C, Denton CP, et al. Association of antiRNA polymerase III autoantibodies and cancer in scleroderma. Arthritis Res Ther. 2014;16(1):R53.

27. Joseph CG, Darrah E, Shah AA, Skora AD, CasciolaRosen L,A, Wigley F,M, et al. Association of the autoimmune disease scleroderma with an immunologic response to cancer. Science. 2014;343:152-7.

28. Steen V, Domsic RT, Lucas M, Fertig N, Medsger Jr TA. A clinical and serologic comparison of African American and Caucasian patients with systemic sclerosis. Arthritis Rheum. 2012;64(9):2986-94.

29. Petersen WG, Zimmerman R. Limited utility of chest radiograph after thoracentesis. Chest.

2000;117(4):1038-42.

30. Aggarwal R, Lucas M, Fertig N, Oddis C, V, Medsger Jr T,A. Anti-U3 RNP autoantibodies in systemic sclerosis. Arthritis Rheumatol. 2009;60(4):1112-8.

31. Sharif R, Fritzler MJ, Mayes MD, Gonzalez EB, McNearney TA, Draeger $\mathrm{H}$, et al. Anti-fibrillarin antibody in African American patients with systemic sclerosis: immunogenetics clinical features and survival analysis. J Rheumatol.

2011;60(4):1112-8.

32. Fertig N, Domsic RT, Rodriguez-Reyna T, Kuwana M, Lucas M, Medsger TA, et al. Anti-U11/U12 RNP antibodies in systemic sclerosis: a new serologic marker associated with pulmonary fibrosis. Arthritis Rheum. 2009;61(7):958-65.

33. Koschik RW, Fertig N, Lucas MR, Domsic RT, Medsger Jr TA. Anti-PM-Scl antibody in patients with systemic sclerosis. Clin Exp Rheumatol. 2012;30(2 Suppl 71):S12-16.

34. Wodkowski M, Hudson M, Proud man S, Walker J, Stevens W, Nikpour M, et al. Clinical correlates of monospecific anti-PM75 and anti-PM100 antibodies in a tri-nation cohort of 1574 systemic sclerosis subjects. Autoimmunity. 2015;3:1-10.

35. Marguerie C, Bunn CC, Copier J, Bernstein RM, Gilroy JM, Black CM, et al. The clinical and immunogenetic features of patients with autoantibodies to the nucleolar antigen PM-Scl. Medicine (Baltimore). 1992;71(6):327-36.

36. Oddis CV, Okana Y, Rudert WA, Trucco M, Duquesnoy RJ, Medsger Jr TA. Serum autoantibody to the nucleolar antigen PM-Scl, clinical and immunogenetic associations. Arthritis Rheum. 1992;35(10):1211-7.

37.•• D'Aoust J, Hudson M, Tatibouet S, Wick J, Canadian Scleroderma Research Group, Mahler M, et al. Clinical and serologic correlates of anti-PM/Scl antibodies in systemic sclerosis: a multicenter study of 763 patients. Arthritis Rheumatol. 2014;66(6):1608-15.

This article provides a descriptive analysis of $\mathrm{PM} / \mathrm{Sc} 1$ positive patient characteristics from the Canadian Scleroderma Research group.

38. Koike M. Dimerization translocation and localization of Ku70 and Ku80 proteins. J Radiat Res. 2002;43(3):223-36.

39. Cavazzana I, Fredi $M$, Taraborelli $M$, Quinzanini $M$, Tincani A, Franceschini F. A subset of systemic sclerosis but not of systemic lupus erythematosus is defined by isolated anti-Ku autoantibodie. Clin Exp Rheumatol. 2013;31(2 Suppl 76):118-21.

40.• Moinzadeh Aberer E, Ahmadi-Simab K, Blank N, Distler JH, Fierlbeck G, Genth E, et al. All participating 
DNSS centers, disease progression in systemic sclerosisoverlap syndrome is significantly different from limited and diffuse cutaneous systemic sclerosis. Ann Rheum Dis. 2015;74(4):730-7.

This manuscript is a descriptive study of SSc-overlap patients in the German Network of Systemic Scleroderma. Anti-Ku and anti-PM/Sc1 patients are described.

41. Rozman B. Prevalance and clinical associations of anti$\mathrm{Ku}$ antibodies in patients with systemic sclerosis: a Europena EUSTAR-initiated multi-centre case-control study. Ann Rheum Dis. 2008;67(9):1282-6.

42. Rigolet AM, Dubourg O, Maisonobe T, Grenier Charuel JL, Behin A, Herson S, et al. Inflammatory myopathies with anti-Ku antibodies: a prognosis dependent on associated drug disease. Medicine (Baltimore). 2012;91(2):95-102.

43. Sharp GC. Current concepts in the classification of connective tissue diseases, overlap syndromes and mixed connective tissue disease (MCTD). J Am Acad Dermatol. 1980;4:269-79.

44. Alarcon Segovia D, Villareal M, Classification and diagnostic criteria for mixed connective tissue disease, mixed connective tissue disease and anti-nuclear antibodies ed, R, Kasukawa Sharp G, editors. Amsterdam: Elsevier; 1987.

45. Doria A, Ghirardello A, de Zambiasi RA, Gambari PF. Japanese diagnostic criteria for mixed connective tissue disease in Caucasian patients. J Rheumatol. 1992;19(2):259-64.

46. Jonsson J, Norberg R. Symptomatology and diagnosis in connective tissue disease, II, evaluations and followup examinations in consequence of a speckled antinuclear immunofluorescence pattern. Scand J Rheumatol. 1978;7(4):229-36.

47. Kahn M, Appelboom T, Syndrom de Shar3rd ed, Les maladies systemiques ed, M, Kahn Peltier A, Meyer O, Peiette J, editors. Paris: Flammarion; 1991.

48.• Kaji K, Fertig N, Medsger Jr TA, Satoh T, Hoshino K, Hamaguchi Y, et al. Autoantibodies to RuvBL1 and RuvBL2: a novel systemic sclerosis-related antibody associated with diffuse cutaneous and skeletal muscle involvement. Arthritis Care Res (Hoboken). 2014;66(4):575-84.

This article presents the identification and clinical associations of anti-RUVBL1 and RuvBL2 with a SSc-overlap presentation.

49. Rodriguez-Sanchez JL et al. A new antibody in scleroderma that recognizes a 90-kDa component of the nucleolus-organizing region of chromatin. J Immunol. 1987;139(8):2579-84

50. Dagher JH, Scheer U, Voit R, Grummt I, Lonzetti L, Raymond Y, et al. Autoantibodies to NOR 90/hUBF: longterm clinical and serological followup in a patient with limited systemic sclerosis suggests an antigen driven immune response. J Rheumatol. 2002;29(7):1543-7.
51. Ulanet DB et al. Autoantibodies against B23 a nucleolar phosphoprotein occur in scleroderma and are associated with pulmonary hypertension. Arthritis Rheum. 2003;49(1):82-92.

52. Hudson $\mathrm{M}$ et al. Clinical significance of antibodies to Ro52/TRIM21 in systemic sclerosis. Arthritis Res Ther. 2012;14(2):R50.

53. Costa S, Mondini M, Caneparo V, Afeltra A, Airo Bellisai F, et al. Detection of anti-IF116 antibodies by ELISA: clinical and serological associations in systemic sclerosis. Rheumatology (Oxford). 2011;50(4):67481.

54. Salazar GA, Assassi S, Wigley F, Hummers L, Varga J, Hinchcliff $\mathrm{M}$, et al. Antinuclear antibody-negative systemic sclerosis. Semin Arthritis Rheum. 2014;44(6):680-6.

55. Shanmugam VK, Swistowski DR, Saddic N, Wang H, Steen VD. Comparison of indirect immunofluorescence and multiplex antinuclear antibody screening in systemic sclerosis. Clin Rheumatol. 2011;30(10):1363-8.

56. Baroni SS et al. Stimulatory autoantibodies to the PDGF receptor in systemic sclerosis. N Engl J Med. 2006;354(25):2667-76.

57. Kuwana $M$, Medsger TA. The clinical aspects of antibodies. 2015 In press.

58. Tan FK, Arnett FC, Antohi S, Saito S, Mirarchi A, Spiera $\mathrm{H}$, et al. Autoantibodies to the extracellular matrix microfibrillar protein fibrillin-1 in patients with scleroderma and other connective tissue diseases. J Immunol. 1999;163(2):1066-72.

59. Riemekasten G, Philippe A, Näther M, Slowinski T, Müller DN, Heidecke $H$, et al. Involvement of functional autoantibodies against vascular receptors in systemic sclerosis. Ann Rheum Dis. 2011;70(3):530-6.

60. Wallukat $\mathrm{G}$, Homuth V, Fischer T, Lindschau C, Horstkamp B, Jüpner A, et al. Patients with preeclampsia develop agonistic autoantibodies against the angiotensin AT1 receptor. J Clin Invest. 1999; 103(7):945-52.

61. Kill A et al. Autoantibodies to angiotensin and endothelin receptors in systemic sclerosis induce cellular and systemic events associated with disease pathogenesis. Arthritis Res Ther. 2014;16(1):r29.

62. Avouac J, Riemekasten G, Meune C. Autoantibodies against endothelin 1 type a receptor are strong predictors of digital ulcers in systemic sclerosis. J Rheumatol. 2015;42:1801.

63. Hu PQ, Fertig N, Medsger Jr TA, Wright TM. Correlation of serum anti-DNA topoisomerase 1 antibody levels with disease severity and activity in systemic sclerosis. Arthritis Rheum. 2003;48(5):1363-73.

64. Kuwana M, Kaburaki J, Mimori T, Kawakami Y, Tojo T. Longitudinal analysis of autoantibody response to topoisomerase I in systemic sclerosis. Arthritis Rheum. 2000;43(5):1072-84. 